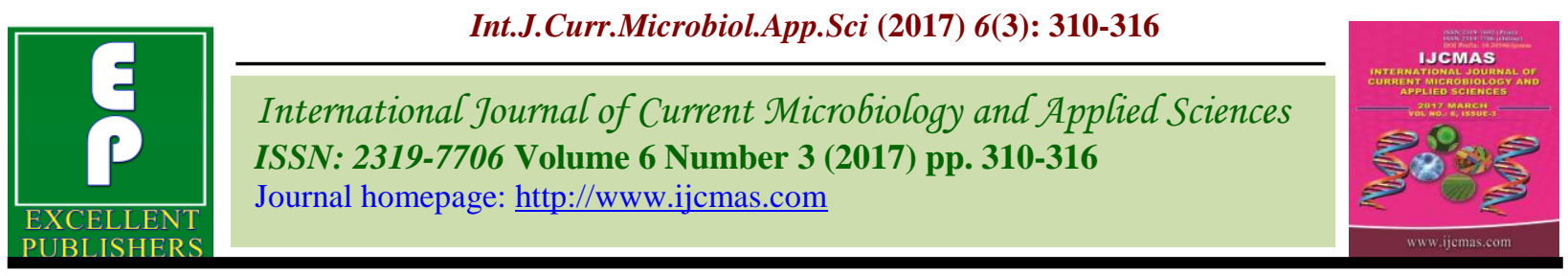

Original Research Article

https://doi.org/10.20546/ijcmas.2017.603.034

\title{
Studies on Mycoflora Population in Various Irrigated Paddy Field Soil at Thanjavur District, India
}

\author{
M. Sangeetha ${ }^{1}$, K. Kanimozhi ${ }^{1}$, A. Panneerselvam ${ }^{1}$ and R. Senthilkumar ${ }^{2^{*}}$ \\ ${ }^{1}$ P.G and Research Department of Botany and Microbiology, A.V.V.M. Sri Pushpam College \\ (Autonomous), Poondi-613503, India \\ ${ }^{2}$ Department of Microbiology, PG Extension Centre, Bharathidasan University, Perambalur- \\ 621107, India \\ *Corresponding author
}

\begin{tabular}{|c|c|}
\hline & A B S T R A C T \\
\hline $\begin{array}{l}\text { Ke y w or d s } \\
\text { Mycoflora, } \\
\text { Aspergillus, } \\
\text { Penicillium and } \\
\text { Paddy field soil. }\end{array}$ & \multirow{3}{*}{$\begin{array}{l}\text { Totally } 3 \text { different irrigated paddy field soils were collected from Thanjavur } \\
\text { district, Tamilnadu and their physico-chemical properties and population } \\
\text { density of mycoflora were analyzed. Among them, } 2 \text { samples were sandy clay } \\
\text { loamy soil and } 1 \text { sample was loamy soil. The physiochemical parameters were } \\
\text { also analysed. The population density of mycoflora was maximum ( } 52 \text { ) } \\
\text { observed in sandy clay loamy soil at Kollakadu, minimum (33) population } \\
\text { density was observed in loamy soil at Pathirankottai. Totally } 22 \text { fungal species } \\
\text { belongs to } 2 \text { genera Aspergillus and Penicillium sp were isolated from the } \\
\text { three different samples. }\end{array}$} \\
\hline Article Info & \\
\hline $\begin{array}{l}\text { Accepted: } \\
\text { 10 February } 2017 \\
\text { Available Online: } \\
10 \text { March } 2017\end{array}$ & \\
\hline
\end{tabular}

\section{Introduction}

Soil is highly complex system, with many components playing diverse function mainly due to the activity of soil organisms (Arunachalam et al., 1997). Soil mycoflora plays a vital role in evaluations of soil conditions and in stimulating plant growth (Christensen, 1989). Microorganisms are beneficial in increasing the soil fertility and plant growth as they are involved in several biochemical transformation and mineralization activities in soils. Type of cultivation and crop management practices found to have greater influence on the activity of soil mycoflora (Deka and Mishra, 1984). Continuous use of chemical fertilizer over a long period may cause imbalance in soil mycoflora and indirectly affect biological properties of soil leading to soil degradation (Chandrasekar et al., 2014).

Fungi are fundamental in soil ecosystem functioning (Manickam and Venkatraman, 1972). Especially in forest and agricultural soils, they play a key role in many essential processes such as organic matter decomposition and element released by mineralization (Bisset and Parkinson, 1979). Fungi are an important component of the soil micro biota (Nagamani et al., 2006). Micro fungi play a focal in nutrient cycling by 
regulating soil biological activity (Alexander, 2001).The quantities of organic and inorganic materials present in the soil have a direct effect on the fungal population of the soil. In addition to chemical fertilizers, wide range of pesticides shows adverse effect on mycoflora which are much useful to maintain soil fertility and eco-balance in the soil atmosphere. The members and kinds of microorganisms present in soil depend on many environmental factors such as the type of nutrients, moisture, degrees of aeration, $\mathrm{pH}$ and temperature etc. The aim of the present investigation is to isolate mycoflora from different agricultural fields and to observe the percentage contribution of different fungal species.

\section{Materials and Methods}

\section{Description of the study area}

The present study focused on the area in Thanjavur district, Tamilnadu state (Lat.10 ${ }^{\circ}$ $47^{\prime} \mathrm{N}$ Long. $79^{\circ} 10^{\prime} \mathrm{E}$ ) with the significant features of granary of south India and also it was a less explored ecosystem for the investigation of mycological population.

\section{Sample collection}

For the isolation and enumeration of fungi, soil samples were collected by aseptic manner at a depth of $5-10 \mathrm{~cm}$ according to the $\mathrm{V}-$ shaped method, at three different locations (Kayavur, Kollakadu and Pathirankottai) of Thanjavur district. From each site five samples were collected and pooled together as one sample. The soil samples were brought to the laboratory and kept in the refrigerator for further process.

\section{Analysis of physico - chemical parameters of the soil}

After removing the debris, the soil samples were suspended in distilled water $(1: 2 \mathrm{w} / \mathrm{v})$ and allowed to settle down the sand particles (Table 1). The $\mathrm{pH}$ of the suspension was determined using $\mathrm{pH}$ meter (Systronics, India). Electrical conductivity of the soil was determined in the filtrate of the water extract using Conductivity Bridge as described by Jackson (1973), Cation exchange capacity (CEC) of the soil was determined by using 1 $\mathrm{N}$ ammonium acetate solution as described by Jackson (1973).

\section{Nutrient analysis}

Organic carbon (OC) content was determined by adopting chromic acid wet digestion method as standard procedure of Walkley and Black (1934), available nitrogen was estimated by alkaline permanganate method (Subbiah and Asija, 1956) and available phosphorus by Bray method (Bray and Kutz, 1945). Available potassium was extracted from soil with neutral $1 \mathrm{~N}$ ammonium acetate (1:5) and the potassium content in the extract was determined by using flame photometer (Standfold and English, 1949). Calcium (Neutral $1 \mathrm{~N} \mathrm{NH}_{4} \mathrm{OAC}$ extractable 1:5) was extracted with neutral $1 \mathrm{~N}$ ammonium acetate and the available calcium in the extract was determined by versenate method (Jackson, 1973). Available micronutrients such as $\mathrm{Zn}$, $\mathrm{Cu}, \mathrm{Mn}$ were determined in the diethyl triamine penta acetic acid extract of soil (Lindsay and Norvell, 1978), Atomic Absorption Spectrophotometer Perkin-Elmer Model 2280. Other nutrients such as magnesium, sodium and available iron were also analysed (Muthuvel and Udayasoorian, 1999).

\section{Isolation of fungi (Walksman, 1922)}

The Potato dextrose agar medium was prepared and poured into the Petriplate. After solidification of medium, serially diluted sample $0.1 \mathrm{ml}$ was directly inoculated on the medium and spread it with help of L-rod. The soil sample was diluted in $10 \mathrm{ml}$ of sterile 
distilled water containing test tube and transferred into the following $10^{-1}, 10^{-2}, 10^{-3}$, $10^{-4}, 10^{-5}$ and $10^{-6}$ dilution. The sample was inoculated on the Potato dextrose agar medium. After inoculation the plates were incubated at $27 \pm 2^{\circ} \mathrm{C}$ for 72 hours.

\section{Identification of fungi}

After incubation period, the fungal culture was picked up with the help of a sterile inoculation needle, and semi permanent slides were prepared using lacto phenol cotton blue. The slides were examined under the microscope for the conidia, conidiophores and arrangement of spores. The observed fungi were identified using standard manual such as, Manual of Soil Fungi (Gilman, 1957) and More Dematiaceous hyphomycetes (Ellis, 1976).

\section{Results and Discussion}

Diversity refers to the variability of life which can be among plants, animals and microorganisms. Fungal diversity, soil was depends upon the physicochemical characterization of the soil (Kennedy et al., 2005; Rangaswamy and Bagyaraj, 1988 and Rani and Panneerselvam, 2010). Exhaustive efforts have been made to explore soil microbial diversity of indigenous community, their distribution and behaviour in soil habitats (Saravanakumar and Kaviyarasan, 2010).

The seasonal variations of soil fungal population in relation to the soil nutrient variability were studied from Paddy field of Thanjavur district, Tamil Nadu viz., Nadur, Orathanadu, Punnainallur and Tholkappiyar Square. About 30 different fungal species belonging to ascomycetes and phycomycetes were isolated by using Potato Dextrose Agar (PDA) medium and identified by using standard manual (Kalaiselvi and Panneerselvam, 2011).
In the present study, soil samples were collected from three different places (premonsoon) of paddy field. Among them, 2 samples were sandy clay loamy soil and 1 sample was loamy soil. The maximum $\mathrm{pH} 8.1$ was observed in Pathirankottai soil sample and minimum 6.7 in Kollakadu sampling station. Total nitrogen, total phosphorus and total potash were highly $(1.27,0.185$ and 1.49 $\mathrm{mg} / \mathrm{g}$ ) recorded in Pathirankottai, minimum in (nitrogen1.27 and phosphorous $0.165 \mathrm{mg} / \mathrm{g}$ ) Kollakadu soil sample. The population density of mycoflora was maximum (52) and moderate (47) observed in sandy clay loamy soil at Kollakadu and Kayavur respectively. The minimum (33) population density was observed in loamy soil at Pathirankottai. Totally 22 fungal species belongs to 2 genera Aspergillus and Penicillium sp were isolated from the three different samples.

Prince and Prabakaran (2012) isolated 50 different species of phycomycetes and deuteromycetes from Thanjavur district, Tamil Nadu viz. Thanjavur and Thiruvaiyaru. The dominant species were Aspergillus niger, Trichoderma koningii followed by $T$. viride, T. harzianum, T. glaucum, P. chrysogenum, $P$. citrinum and Botrytis cinerea from the sugarcane field soils of Thanjavur in various seasons. Whereas, in Thiruvaiyaru soils the dominant species were A. niger, Gliocladium virens, $T$. koningii, A. oryzae, F. oxysporum, $P$. chrysogenum and $T$. viride respectively. Total fungus in two station, they are 37 species belongs to 16 genera were isolated from Thanjavur station, and 35 species belongs to 15 genera were isolated from Thiruvaiyaru station. Similarly, in the present study, 22 different fungi species were isolated. Among the 22 species 19 species belongs to Aspergillus species and 3 species belongs to Penicillium species.

Simple correlation co-efficient (r) values were derived for the variables and the results are presented in tables 2 and 3. 
Table.1 Analysis of physico-chemical properties of soil samples from three different agricultural field of Kayavur, Kollakadu and Pathirankottai

\begin{tabular}{|c|c|c|c|c|c|c|c|c|c|c|c|c|}
\hline S.no & $\mathrm{pH}$ & Density & EC & OC & \multicolumn{3}{|c|}{ Total nutrient $\mathrm{mg} / \mathrm{g}$} & \multicolumn{5}{|c|}{ Available micronutrient (\%) } \\
\cline { 6 - 13 } & & $\left(\mathrm{g} / \mathrm{cm}^{3)}\right.$ & $\left(\mathrm{dcm}^{-1}\right)$ & $(\%)$ & $\mathrm{N}$ & $\mathrm{P}$ & $\mathrm{K}$ & $\mathrm{Zn}$ & $\mathrm{Cu}$ & $\mathrm{Fe}$ & $\mathrm{Mn}$ & $\mathrm{B}$ \\
\hline 1 & 7.2 & 1.360 & 0.54 & 0.76 & 1.25 & 0.142 & 1.37 & 1.36 & 1.60 & 8.40 & 3.10 & 0.390 \\
\hline 2 & 8.1 & 1.520 & 0.36 & 0.79 & 0.75 & 0.165 & 1.28 & 1.56 & 2.80 & 9.10 & 4.35 & 0.580 \\
\hline 3 & 6.7 & 1.110 & 0.69 & 0.97 & 1.27 & 0.185 & 1.49 & 1.68 & 2.92 & 8.27 & 4.68 & 0.520 \\
\hline
\end{tabular}

Table.2 Correlation between the number of colonies and physico-chemical parameters of three different station-pre monsoon

\begin{tabular}{|l|l|l|l|l|l|l|l|l|l|l|l|l|}
\hline & TNC & PH & OC & EC & AN & AP & APO & AZ & CU & FE & MN & B \\
\hline TNC & 1 & & & & & & & & & & & \\
\hline PH & -0.987 & 1 & & & & & & & & & & \\
\hline OC & 0.792 & -0.683 & 1 & & & & & & & & & \\
\hline EC & $0.999^{*}$ & -0.994 & 0.759 & 1 & & & & & & & & \\
\hline AN & 0.828 & -0.908 & 0.314 & 0.856 & 1 & & & & & & & \\
\hline AP & 0.500 & -0.352 & 0.924 & 0.454 & -0.072 & 1 & & & & & & \\
\hline APO & 0.997 & -0.970 & 0.840 & 0.991 & 0.779 & 0.569 & 1 & & & & & \\
\hline AZ & 0.371 & -0.215 & 0.861 & 0.322 & -0.214 & 0.990 & 0.446 & 1 & & & & \\
\hline CU & 0.082 & 0.081 & 0.673 & 0.030 & -0.491 & 0.904 & 0.164 & 0.956 & 1 & & & \\
\hline FE & -0.930 & 0.977 & -0.512 & -0.948 & -0.976 & -0.146 & -0.896 & -0.003 & 0.291 & 1 & & \\
\hline MN & 0.198 & -0.036 & 0.755 & 0.146 & -0.386 & 0.948 & 0.278 & 0.984 & 0.993 & 0.177 & 1 & \\
\hline B & -0.309 & 0.460 & 0.335 & -0.358 & -0.789 & 0.669 & -0.230 & 0.769 & 0.922 & 0.638 & 0.871 & 1 \\
\hline
\end{tabular}

*. Correlation is significant at the 0.05 level.

TNC- Total No. of colony, OC- Organic carbon, EC- Electrical conductivity, AN- Available nitrogen, AP Available phosphorus, APO - Available potassium, AZ - Available zinc, AC - Available copper, $\mathrm{Fe}$ - Available iron, Mn- Available manganese, B-boron 
Table.3 Diversity of fungal colonies in different soil samples

\begin{tabular}{|c|c|c|c|c|}
\hline \multirow[t]{2}{*}{ S. No } & \multirow[t]{2}{*}{ Name of the species } & \multicolumn{3}{|c|}{ Number of colonies } \\
\hline & & Kayavur & Kollakadu & Pathirankottai \\
\hline 1 & Aspergillus aureolatus & 3 & 3 & 2 \\
\hline 2 & A. avenscenus & 4 & 4 & 2 \\
\hline 3 & A. arenarius & 3 & 2 & 2 \\
\hline 4 & A. candidus & 4 & - & - \\
\hline 5 & A. duricaulis & - & 3 & 2 \\
\hline 6 & A. fumigatus & 3 & 5 & 2 \\
\hline 7 & A. janus & 2 & - & - \\
\hline 8 & A. niger & 5 & 4 & 2 \\
\hline 9 & A. puniceus & 2 & 4 & 3 \\
\hline 10 & A. panamensis & 2 & 2 & 3 \\
\hline 11 & A. repens & 2 & 2 & 1 \\
\hline 12 & A. sparsus & 2 & 1 & - \\
\hline 13 & A. speluneus & 2 & 4 & 1 \\
\hline 14 & A. subolivaceus & - & 3 & 1 \\
\hline 15 & A. tamari & 1 & - & 2 \\
\hline 16 & A. terreus & 1 & - & - \\
\hline 17 & A. terricola & 2 & 1 & 1 \\
\hline 18 & A. ustus & 4 & 1 & 1 \\
\hline 19 & A. wentii & 2 & 3 & - \\
\hline 20 & Penecillium $s p$ & - & 4 & 3 \\
\hline 21 & P. frequentans & - & 2 & 4 \\
\hline 22 & P. granulatum & 3 & 4 & 1 \\
\hline \multicolumn{2}{|c|}{ Total number of colonies } & 47 & 52 & 33 \\
\hline
\end{tabular}

These fungal species belongs to the phylum Ascomycetes, and dominant fungal species are Aspergillus sp. Gaddeya et al., (2012) reported that the 15 species of fungi belongs to 6 genera isolated from different crop field's soil samples in Salur Mandal, Karnataka District. 


\section{Statistical analysis}

Percentage of Contribution $=$

Total no of cfu of an individual species

Total no of cfu of all species

In conclusion, the soil samples were collected from three different places of paddy field. Among them, 2 samples were sandy clay loamy soil and 1 sample was loamy soil. The physiochemical parameters were analysed and correlated with mycological population. The population density of mycoflora was maximum observed in sandy clay loamy soil at Kollakadu minimum in loamy soil at Pathirankottai. Totally 22 fungal species belongs to 2 genera Aspergillus and Penicillium sp. were isolated from the three different samples. The population density of mycoflora in agricultural fields were found to be regulated by many factors like soil fertility, humidity, organic and inorganic materials type and texture of soil.

\section{References}

Ains woth, G.C. and G.R. Bisby. 1995. Dictionary of fungi, Common wealth Mycological Institute Kew, surrey, pp445.

Alexander, M. 1977. Introduction to soil Microbiology, John Wiley and sons, New York.

Alexander, M. 2001. Introduction to soil Microbiology, Plant pathology and Biotechnology; New age International Publishers, 4: 157-162.

Arunachalam, K.M., Arunachalam, R.S., Tripathi and Pandy, H.N., 1997. Dynamics of microbial population during the aggradations phase of selectively logged sub-tropical humid forest in north-eastern India. Trop. Ecol., 38: 333-341.

Bissett, J. and Parkinson, D. 1979. Functional relationships between soil fungi and environment in alpine tundra Can $j$. Bot., 57: 1642-1659.

Bray, R.H. and Kutz, L.T. 1945. Determination of total organic and available phosphorus in soils. Soil Sci., 59: 39-45.

Chandrashekar, M.A., Sowmya Pai, K.and Raju, N.S. 2014. Fungal Diversity of Rhizosphere Soils in Different Agricultural fields of Nanjangud Taluk of Mysore District, Karnataka, India. Int. J. Curr. Microbiol. App. Sci., 3(5): 559-566.

Christensen, M. 1989. A view of fungal ecology. Mycologia, 81: 1-1-9.

Deka,H.K and Mishra R.R. 1984. Distribution of soil microflora in jhum fallows in NE India. Acta Botanica Indica., 12:180184.

Ellis, M.B. 1976. More dematiaceous hyphomycetes. Common Wealth Mycological Institute, Kew, Surrey England.

Gilman, J.C. 1957. A manual of soil fungi, Revised $2^{\text {nd }}$ edition, Oxford and IBH publishing company (Indian Reprint) Calcuta, Bombay, New Delhi-450.

Gaddeyya, G., P.S. Niharika., P. Bharathi and P.K. Ratna kumar. 2012. Isolation and identification of soil mycoflora in different crop fields at Salur Mandal, Adv. Appl. Sci. Res., 3(4): 2020-2026.

Jackson, M.L. 1973. Soil chemical analysis. Prentice Hall of India Pvt. Ltd., New Delhi.

Kalaiselvi, S. and Panneerselvam, A. 2011. Ecology of soil fungi in paddy field of Tamilnadu-Thanjavur District. Der Chemica Sinica, 2(2): 9-19.

Kennedy, N.M., D.E. Gleeson, J.Connolly and N.J.W. Clipson. 2005. Seasonal and management influences on bacterial community structure in an upland grassland soil FEMS Microb. Ecol., 53: 329-337. 
Lindsay, W.C. and Norvell, A., 1978. Development of a DTPA soil test for zinc, iron, manganese and copper. Proc. Soil Sci. Soc. Am., 42: 421 - 428.

Manickam, T.S and Venkataraman, C.R. 1972. Effect of continuous application of manures and fertilizers on some physical properties of soils. II under irrigated conditions. Madras Agri. J., 59: 508-512.

Muthuvel, P. and Udayasoorian, C. 1999. Soil, plant, water are agrochemical analysis. Tamilnadu, Agricultural Unviersity, Coimbatore, India.

Nagamani, A., Kunwar, I., and Manoharachary, C., 2006. Hand book of soil fungi, I.k. international Pvt. LTd,

Prince, L. and Prabakaran, P. 2012. Studies on the Soil Mycoflora from the sugarcane field in Thanjavur District Tamilnadu. J. Microbiol. Biotech. Res., 2(1): 63-69.

Rangasawami, G. and Bagyaraj, D.J. 1988. Agricultural Microbiology, $2^{\text {nd }}$ edition published by Prentice Hall of India Pvt. Ltd. N. Delhi.
Rani, C., and Paneerselvam, A. 2010. Fungal diversity in the sediments of point calimere, East coast of India. J. Pure. Appl. Microbiol., 4: 1999-2006.

Saravanakumar, K., and Kaviyarasan, V. 2010. Seasonal distribution of soil fungi and chemical properties of montane wet temperate forest types of Tamil Nadu. African. J. Plant Sci., 4(6): 190-196.

Standfold, S. and English, L. 1949. Use of flame photometer I rapid soil test for $\mathrm{K}$ and Ca. Agron. J., 41: $446-447$.

Subbaiyah, B.V. and Asija, G.L. 1956. A rapid method for estimation of available nitrogen in soil. Curr. Sci., 25: 258 260.

Walkey, A. and Black, I.A. 1934. An experimentation of the organic matter and proposed modification of the chronic acid nitration method. Soil Sci., 37: $29-38$.

Waksman, S. 1922. A method of counting the number of fungi in the soil J. Bact., 7: 339-117.

\section{How to cite this article:}

Sangeetha, M., K. Kanimozhi, A. Panneerselvam and Senthilkumar, R. 2017. Studies on Mycoflora Population in Various Irrigated Paddy Field Soil at Thanjavur District. Int.J.Curr.Microbiol.App.Sci. 6(3): 310-316. doi: https://doi.org/10.20546/ijcmas.2017.603.034 